\title{
Licence to kill? On the organization of destruction in the 21st century
}

\author{
Brian P. Bloomfield, ' Gibson Burrell ${ }^{* *} \&$ Theo Vurdubakis ${ }^{*}$ \\ *Lancaster University, UK \\ ${ }^{* *}$ University of Leicester and Manchester Business School, UK
}

\begin{abstract}
War, the organized destruction of human beings, of human lifeworlds and modes of livelihood, has long been regarded as outside the usual preoccupations of organization studies. And yet, as the various on-going "asymmetric wars" increasingly become the taken for granted background noise of contemporary life, this aloofness becomes difficult to maintain. This special issue then is an initial contribution to a long overdue conversation. By way of introduction to the articles that comprise the special issue we seek to highlight some of the key connections between organization theory, forms of organized destruction and their ongoing mutations in the still young, but already quite bloody, $21^{\text {st }}$ century.
\end{abstract}

\section{Keywords}

organized destruction, organization, warfare, the military

The final version of this paper was published as an editorial introduction to a special issue of the journal Organization on the theme of 'the organization of destruction'.

Volume: 24 issue: 4, page(s): 441-455 Copyright ( [2017] (The Authors)

Article first published online: July 6, 2017; Issue published: July 1, 2017 DOI: https://doi.org/10.1177/1350508417700404 


\section{Introduction}

"You may not be interested in war", goes the quip usually misattributed to Trotsky, "but war is interested in you". With some exceptions, (e.g. Grint, 2008; Godfrey et al 2012; Chwastiak, 2015; Grey 2009), organization studies has shown relatively little interest in war. The existence, or even ubiquity, of forms of organization predominately geared towards the production of death and rubble, has tended to remain a kind of absent presence within the discipline - including its more 'critical' variants. ${ }^{1}$ There are those like Albrow (1970) for instance, who argued that the sociology of organisations is quite distinct from organisation theory because the former is a branch of the social sciences whilst the latter is a pragmatic branch of management. In this history (which has yet to be properly written) 'organization theory' arises in name in the halls of Carnegie Mellon University in the mid-1950s and seeks to roll back the burgeoning bureaucracy of the American state. It is anti-bureaucratic in ideology and a servant, not of the state but of (big) business. In this account, 'organization theory' is concerned with production, construction, and good order and thus appears prima facie to have little to do with war, the study of which belongs somewhere else -politics, history or military sociology for example. At the same time, the relationship between the organization of production (as exemplified by the factory) and the organization of destruction (as exemplified by the battlefield) is as longstanding as it is complex (Pickering, 2001:165; Costea and Amiridis, this volume). As is well known, Max Weber (1919) argued that the routines of state bureaucracies are upheld by the monopolization of violence whilst the institutional form of the 'arsenal' has long been the site for the development and testing of new management techniques such as Taylorism in Watertown or Whitney's 'American System of Manufacture'. More recently, the RAND Corporation has become synonymous with the development of military-managerial techniques which aspire to be as applicable to the organization of destruction as they were to the organization of production (e.g. McCann, this issue). It should be apparent however, that warfare does not merely constitute a disruption of organized life but is itself a highly complex phenomenon "deeply sutured into modern institutions and practices" (Dillon and Reid, 2009:9). Thus although the activity of mutual destruction - of human beings, lifeworlds and modes of livelihood - may appear far from the field's typical preoccupations, it nevertheless increasingly reflects the 'managed' character of the contemporary world. Societies, it has often been said, "make war the same way they make wealth" (Cebrowski and Garstka, 1998; Toffler and Toffler, 1990). 
As the second decade of the 21 st century comes to a close, we believe that there is a pressing need to better understand contemporary forms of 'organized destruction', their sociotechnical apparatuses, and their ongoing mutations. With this objective in mind, the contributions to this special issue draw on a range of approaches, including inter alia, business and management studies, war studies, science and technology studies, sociology, history and philosophy in order to address a number of pertinent questions such as: Who or what are the agencies of organized destruction and how are they enacted? What are the spaces of organized destruction and how are they (re)produced? What are the technologies of organized destruction and what is their role in the 21 st century? What are the narratives we organize destruction by? What are the ethics of organized destruction and how are they changing? Such questions, we will argue, (re)connect us to longstanding concerns in the study of organizations.

\section{War as Organization}

It is by now a commonplace that we live in an era of crisis, an era characterised by multiple cycles of violence without any discernible end. Images of the destruction of Aleppo, the battle for Mosul, or the conflict in Ukraine are, at the time of writing, flooding the virtual spaces that now mediate (high/post) modernity's relationship with its violent underside. Other, no less brutish conflicts, such as what has been justly called the Great African War which over the last two decades may have caused up to 5.5 million deaths (Reyntjens, 2011; Coghlan et al, 2006) - do not fit well into political and media agendas and remain largely unreported. The need to understand this wide range of developments and events, in which processes of organized destruction play a central role, remains more urgent than ever. And yet, organization theory still appears unable or unwilling to meet this need. From the point of view of the mainstream at least, the very notion of an 'organized destruction' has come to appear as a problematic, even illegible, object.

A key trope in management and organization studies, argues Tsoukas (1998), is that of cosmogenesis. In mainstream accounts, and in line with various creation myths to be found around the world, the assumption is made that orderly reality (Greek 'cosmos') is wrestled out of originary chaos, prevails and continues to do so. The task of organization theory (in Albrow's [1970] sense above) is to understand and facilitate this process of overcoming fathomless existence, of transcending chaos, of repairing social disorder - even, or especially in moments of violent transformation. Forms of social organization, as Parsons (1937) put it, 
should be understood as solutions to the "Hobbesian problem of order" - originally and starkly posed as the overcoming of humanity's "state of nature": the bellum omnium contra omnes (Hobbes, 1651). In terms of the concerns of this special issue, Hobbes's hypothetical "war of all against all" would not constitute a 'war'. Whereas violence has arguably always been with us, 'war' in the sense invoked here, is not "an aggregation of violent acts that finally reaches a given threshold of carnage" (Whitehead and Finnström, 2013:7). Rather, as Malešević (this volume) notes, war presupposes and requires a high level of organization. Students of social organization, such as Weber (1919), Elias (2000 [1939]) or Foucault (1979) have all in diverse ways highlighted how "the monopolization of physical violence" (e.g. Elias op cit Vol.II: 2) goes hand-in-hand with the imposition of discipline across all areas of social life. Organized destruction entails inter alia the suppression of random (i.e. un-licenced) acts of violence. It requires, among other things, the control of what Marlantes (2012:61-62) for instance describes as the "deep savage joy in destruction" which combatants sometimes feel, noting that " $[\mathrm{t}]$ he least acknowledged aspect of war, today, is how exhilarating it is".

“Organized violence is focused violence" (Marvin and Ingle, 1999:72), "monopolization" in this sense, specifies who may legitimately kill and who may be killed (Weber, 1919). It is thus the organization rather than the eradication of violence that becomes the task of group membership (Marvin and Ingle, ibid). 'Monopolization', we might say, redirects the incidence of violence from the centre of the social group to its borders. At the same time, licenced violence is always a problematic operation. The evidence indicates that at any given time there is only a minority that becomes addicted to what Elias (2000 [1939]) calls the “savage joys" of war (Grossman, 2009; Marlantes, 2012; Burke, 1999; Malešević, this issue). In his study of the Holocaust (which consumed Elias' family), Bauman (1989) argues that (most) people are prone to feelings of "animal pity" and thus have a deep-seated aversion to killing their fellow humans. For the organizers of the Final Solution, he notes, this emerged as a significant obstacle. Initial attempts to shoot the Jews proved relatively "inefficient" because of the emotional toll which having to witness their victims' suffering would exact on even hardened soldiers. The problem was therefore solved by (re)organizing the process of extermination as a bureaucratic-industrial operation, one which better permitted the creation of physical and emotional distance between victim and executioner. 
Grossman (2009) presents a wide range of (admittedly) circumstantial evidence, which indicates that similar issues arise in combat itself. Thus, it has been estimated that during WWII, less than $20 \%$ of American servicemen ever fired their weapons at their opponents. This, in turn, echoes the experience of earlier wars. For instance,

"after the Battle of Gettysburg, 27,574 muskets were recovered from the battlefield. Of these, nearly ninety per cent $(24,000)$ were loaded. 12,000 of these loaded muskets were found to be loaded more than once, and 6,000 of the multiply loaded weapons had from 3 to 10 rounds loaded in the barrel. One weapon had been loaded 23 times" (Grossman, op cit:23).

A double load (i.e. loading the weapon again without having fired it) renders the musket dangerous to the user because it would be liable to explode if/when subsequently fired. In the heat of battle, one can imagine some muskets being accidentally double-loaded in panic. Nevertheless, the scale of the phenomenon indicates that in all likelihood soldiers were going 'through the motions' of fighting for the benefit of their officers and even in order to spare the lives of their enemies. Grossman argues that authorized killing has a number of organizational preconditions, including: close supervision by (respected) "authority figures", "group absolution" in the form of peers who accept and demand such killing; the engineering of physical and/or emotional distance from the victim(s) who come to be defined as savage, inhuman "Others"; and the performance of a cost-benefit analysis that establishes the killing of the victim as the lesser evil. Fulfilling such preconditions will facilitate but, of course, cannot guarantee the disciplined exercise of organized violence.

To sum up, we might say that organized destruction requires the simultaneous solution of the double problem of reliably generating and disciplining violence. The various solutions that have been historically attempted constituted an implicit theme of Max Weber's study of how "[t]he masses are ...conditioned and trained for discipline in order that their optimum of physical and psychic power in attack may be rationally calculated" (Gerth and Mills 1991 [1948]: 254). Weber sought to chart the advances and retreats of military discipline through the various formations under which differing organisational principles have been historically expressed - from early arrangements such as "warrior communism", to that of the modern military, "essentially a bureaucratic organization administered by that peculiar type of military functionary, the 'officer"' (Parsons and Henderson, 1947: 334-5). 
"Discipline has grown on the basis of an increased concentration of the means of warfare in the hands of the warlord. This has been achieved by having a condottiere recruit mercenary armies...in the manner of a private capitalist...It was followed by the raising and equipping of standing armies by means of political authority and collective economy....It began with Maurice of the House of Orange, proceeded to Wallenstein, Gustav Adolf, Cromwell, the armies of the French, of Frederick the Great, and of Maria Theresa; it passed through a transition from the professional army to the people's army of the French Revolution and from the disciplining of the people's army by Napoleon into a partly professional army. Finally universal conscription was introduced during the nineteenth century" (Gerth and Mills, 1991 [1948]: 260).

Weber's interest in such matters appears to have been practical as well as theoretical. It is said (MacRae, 1974: 52-3) that in the last year of his life, in a lecture in Munich, he informed students that "I have no political plans except to concentrate all my intellectual strength on one problem, how to get once more for Germany a great General Staff'. War, it seems, has long been interested in the study of organization (see also Paparone, this issue).

The growth in bureaucracy that attracted the attention of those who sought to call themselves organization theorists in the late 1940s within Western Europe and the USA was a direct result of the massification of war and the rise of an industrial-administrative apparatus able to undertake 'Total War'. Operational Research and Organizational Psychology, for instance, were managerial disciplines that thrived in the years of WWII, seeking to improve the performance of defensive and offensive weaponry and the resilience of troops and civilians to the depredations of war. It was here within the state's administrative apparatus that the focus upon the systems and structures best able to allow the warfare state of one's own to resist the ravages of the Other were honed. ${ }^{2}$

\section{Destruction}

In On the Natural History of Destruction, W.G. Sebald (2003: 27-8) writes of the effects of Allied bombing on German cities like Hamburg: "Behind collapsing facades, the flames shot up as high as houses, rolled like a tidal wave through the streets at a speed of over a hundred and fifty kilometres an hour, spun across open squares in strange rhythms like rolling 
cylinders of fire. The water in some canals was ablaze. The glass in the tramcar windows melted; stocks of sugar boiled in the bakery cellars. Those who fled from their air-raid shelters sank, with grotesque contortions, in the thick bubbles thrown up by the melting asphalt... Other victims had been so badly charred and reduced to ashes by the heat, which had risen to a thousand degrees or more, that the remains of families consisting of several people could be carried away in a single laundry basket." Amid this desolation, survivors wandered seemingly unable to even look at the horrors that surrounded them. From Guernica to Coventry, to Dresden, to Warsaw, to Leningrad, to Nanjing, to Nagasaki, the very societies that boastfully claimed to represent the pinnacle of human civilization, appeared bent on worldwide destruction. Clearly destruction of this kind presupposes and demands remarkable feats of organization (Nearing, 1931) - a form of reverse cosmogenesis.

Two dangers constantly "threaten the world" argued Robert Cooper (1986: 299) quoting Paul Valery: "order and disorder". In 'organized destruction' the orderly, as it were, production of death, dis-order and dis-organization, Cooper's two dangers appear entwinned. Organized destruction appears as an oxymoronic enterprise where order and disorder, organization and disorganization, security and danger are forever in the process of exchanging masks. Thus, from WWI to Vietnam to Iraq and beyond, historians have noted how the sociomaterial apparatuses of organized destruction often (or perhaps typically) acquire a momentum of their own which tends to render them inimical to instrumental ends-means calculation or to the dictates of good sense (e.g. Taylor, 1961; 1969; 1970; Hastings, 2010; Tuchman, 1990; Grayling, 2016, Sebald ibid). For instance, there is evidence that " $[w]$ hen the British, in their turn, went over to the bombing of Germany, this did more harm to themselves than to the Germans - that is, [the bombing] used up more men and materials than it destroyed German" (Taylor, 1961: 116). ${ }^{3}$ Organized destruction we might say is a monster adept at deceiving itself. Viewed in this light the victims of conflict, argues Sebald (2003:20), are not "sacrifices made as the means to an end of any kind, but in the most precise sense are both the means and the end themselves" (after Scarry, 1985: 74).

Much reference has been made - by journalists, social commentators and policy pundits - to contemporary Western electorates' increasing aversion to casualties incurred in the pursuit of political objectives, however worthy such objectives may appear. (The Vietnam War, folk wisdom has it, was lost in the living rooms of America - e.g. Hallin, 1986). Norbert Elias (1985) suggested that such dispositions are characteristic of societies that have undergone a 
prolonged period of physical pacification, so that violent confrontations are no longer seen as normal occurrences but are typically experienced at a distance, minimally and vicariously through the lens of the mass media. Euro-Americans, claims Ignatieff (2000a: 186) have increasingly come to view death on the battlefield as something of a scandal wherein:

"the gradual banishment of death [is] the over-riding pre-occupation of civilian society. As infant mortality has declined, as life expectancy has increased, as peace has become a settled expectation of civilian populations, the idea of martial sacrifice and the nobility of death in combat have ... [come to be] seen as increasingly implausible to cultures raised to count on a full adult life."

Changes in Euro-American social norms regarding the circumstances in which it is morally and politically acceptable to place lives - not merely one's own but also the enemy's - at risk means that military commanders and their political masters have had to come up with novel strategies

"that not only keep their own casualty levels low, but also respect the expectation bordering on moral presumption - that fire will be directed with precision and only against targets of evident military value" (Freedman, 1998: 70).

In the light of such demands for more manage-able forms of organized destruction, it is hardly surprising that technology has come to be seen as the deus ex machina, the midwife of a Revolution in Military Affairs (RMA e.g. Lefebvre et al, 1996; Freedman, 1998) which is transforming not only the tools, but also the nature and morals of warfare (see also Shah, this issue). The "development of precision-targeted" weaponry such as drones and 'smart' missiles is said to signal the end of the mass mobilizations and industrialized slaughter of $20^{\text {th }}$ century war (e.g. Pinker, 2011; 2013; Singer, 2011; cf Malešević, this issue; Paparone, this issue). By the last decade of the last century, it was becoming a commonplace that (post-Gulf War I) warfare increasingly "reflects the new form of economy that has been springing up in the West and in Japan" (Toffler and Toffler, 1990). What we are witnessing, Toffler and Toffler (1990) contend, is a "de-massification of destruction" which closely parallels the ongoing Post-Fordist "de-massification of production". The organization of production and the organization of destruction thus appear increasingly indebted to a common managerial imaginary. 
In the heady days before the imbroglios of the wars in Syria, Iraq and Afghanistan, the rhetoric of the RMA gave rise to hopes (and fears) that the conduct (as well as the aims) of warfare had been dramatically altered. It appeared to enable "our" agents of destruction to pose as unwilling killers engaged in essentially humanitarian interventions (Marvin and Ingle, 1999:80). NATO's 11-week Kosovo campaign in 1999 - widely acclaimed as epitomising the RMA's new virtual/virtuous mode of warfare (Ignatieff, 2000a) - was successfully conducted without incurring a single NATO combat casualty. It thus gave the impression that a technical-managerial 'fix' to the tragedies of war can indeed be found: "Precision guidance, plus stealth bombers, allowed NATO to take the war "downtown" to Belgrade, in other words, to risk strikes at sensitive targets even in the presence of international TV crews" (Ignatieff, 2000b).

When robots are increasingly expected to "do the dying" (Ramo, 2011) then we can indeed be said to inhabit the first "post-heroic" age of warfare (Luttwak, (1995; 1999; cf. Costea and Amiridis, this issue). The (gendered) figure of the 'warrior' thus appears to be in crisis:

\footnotetext{
"The tacit contract of combat throughout the ages has always assumed a basic equality of moral risk: kill or be killed. Accordingly violence in war avails itself of the legitimacy of self-defence. But this contract is void when one side begins killing with impunity" (Ignatieff; 2000a: 161).
}

But although incontestably a propaganda triumph for the RMA, in strictly military terms the Kosovo "virtual" campaign was far less effective than its iconic status suggests (e.g. see Menon, 2016; Garton-Ash, 2000a;b). ${ }^{4}$ In terms of the broader picture, the weapons and concepts of the RMA/'third wave" warfare remain troubled by the spectres of their Others: the apparatuses of mass destruction represented inter alia by the nuclear arsenals with which they find themselves in a largely unplanned co-habitation (e.g. Cimbala, 2012).

Furthermore, as former Pentagon insider Rosa Brooks (2016) argues, rather than the worldwide decline of armed conflict confidently predicted by Pinker (2011), Goldstein (2011) or Singer (2011), 'war' appears to be undergoing an expansion (see also Gregory, 2011). This is reflected, in among other things, the "seemingly endless proliferation of war modifiers": unconventional war; irregular war; asymmetric war; war of the third kind; new war; chaoplexic warfare; humanitarian intervention; etc. (Corn, 2010: 2). 'War' no longer 
names temporally and spatially discrete events situated in between periods of 'peace'. Wars are no longer 'declared' and increasingly overflow "all boundaries and limits" (Qiao and Wang, 1999). A prominent characteristic of "the new wars", argues Žižek, is that it may "not even be clear whether it is a war or not" (Deichmann et al, 2002: 8). As Abizaid and Brooks (2014: 12) note, in the war on terror the war is wherever the terrorists might be: "[b]asic categories such as 'battlefield', 'combatant' and 'hostilities' no longer have clear or stable meaning". It is becoming more and more vague who now constitutes an 'enemy' or who is to count as a 'non-combatant' (Brooks, 2016: 9). Adversaries seem to constantly multiply, mutate and seldom wear uniforms. Arsenals continually expand to include anything from trucks (Bergen, 2016) to IEDs, "biochemical agents ... computer viruses, net browsers and financial derivative tools" (Qiao and Wang, 1999). It is therefore not entirely surprising that the US military appears currently engaged in an ever widening range of (formerly nonmilitary) activities, from small business development in Africa, to the education of judges and parliamentarians in Afghanistan, to the development of television soap operas in Iraq. War and its apparatuses, Brooks (2016: 9) argues, can no longer "be kept in tidy little boxes". From the capitals of Europe to the villages of Waziristan, from the Caucasus to the Congo, spectres of 'organized destruction' (including 'terror' and the 'war on terror') increasingly haunt the spaces and rituals of $21^{\text {st }}$ century life.

\section{Wars on Terror and the Terrors of War}

\section{Friday the 13th}

In the early hours of November $13^{\text {th }} 2015$, British citizen and former IT salesman Mohammed Emwazi, who had acquired infamy as 'Jihadi John', ISIL's masked executioner, was reported killed along with a colleague ${ }^{5}$ by a US Reaper drone in Raqqa, the organization's Syrian stronghold. British Government sources were quick to emphasise that Jihadi John's assassination had been crucially facilitated by work carried out by $U K$ military and security forces. His killing, we are told, was the culmination of many months of effort to identify and locate the person in the mask whose multiple video beheadings of Western hostages had been broadcast around the world.

Within hours of the announcement of Emwazi's death, the (at times vengeful) media commentary was disrupted by reports of suicide bombings at the Stade de France in Paris where a football match between France and Germany was underway in the presence of French President François Hollande and German foreign minister Frank-Walter Steinmeier. 
Further reports quickly followed, of shootings and suicide bombings taking place all over Paris culminating with news of a massacre at the Bataclan theatre on the Boulevard Voltaire where a rock concert by the American band Eagles of Death Metal was taking place. By the end of the day, the attacks had claimed over 130 lives with three times that number injured, many of them critically. It ranked as the deadliest day in Paris since the end of WWII. The alleged planners of the Paris attacks were in turn themselves reported killed a year later by US drone strikes in Syria (BBC, 2016b).

Even in the course of this one-day, we can glimpse something of the complexity of the questions that motivate this special issue. The killing of 'Jihadi John' appears, at first sight, as an ideal-typical example of Toffler's (1991) 'Third Wave' warfare. His death, we are reminded, is the outcome of complex agencements (Deleuze, 2007) of actors, entities and mediations (including police forces, military and security services, intelligence organizations and their technologies, remote operators and local informants). The sociotechnical apparatuses of the RMA appear able to reach into, what MI6 Chief Alex Younger (BBC, 2016a) calls, the "ungoverned spaces" of the periphery and "vaporise" a named individual. The machineries of 'virtual'/'third wave' warfare (Ignatieff, 2000a,b) appear to recast spatial relations. Thus Emwazi's killing has no 'simple location'. It occurs as it were, simultaneously in the US, Britain and Syria (Chamayou, 2015). His executioners appear to wield a level of 'panoptic' control far beyond the dreams of Bentham (1791). Their hovering "eyes in the sky" often give them a "close and personal" view of their targets whom they may observe "for weeks even months, seeing them go about the routines of daily life, before one day watching on-screen as they are obliterated" (Abizaid and Brooks, 2014: 25). ${ }^{6}$ In relation to Grossman's (2009) model cited earlier, the killing, paradoxically, appears to happen both 'near' and 'far', combining intimacy and distance. Drone 'pilots' appear to embody Luttwak's $(1995 ; 1999)$ post-heroic age. They resemble, so to speak, fallen angels who wear flying suits while working shifts in apparent safety: implementing bureaucratic procedures, manipulating symbols on screens - not unlike, one could say, other 'Information Age workers' (Castells, 1996).

Such agencements gesture towards a reassuring notion of "“war' as a distinct sphere, one that should be kept from intruding into the everyday world of offices, shopping malls, schools, and soccer games" (Brooks, 2016: 9). Framed in this way, death and destruction are made to appear manageable (Butler, 2010). In turn, this very manage-ability is said to go hand-in- 
hand with a new ethos of "targeted" killing (Der Derian, 2009). In terms of EuroAmerican ethical sensibilities, (e.g. Pinker, 2011; 2013; Singer, 2011) the "surgical" precision of Jihadi John's own demise is contrasted to the sheer "medieval barbarity" of his multiple beheadings (The Mirror, $14^{\text {th }}$ Nov. 2015). Emwazi's victims we are told, died in terror, their suffering gloated over and broadcast across the Internet to feed ISIL's propaganda machine. By contrast, as we have seen, the sociomaterial apparatuses of the RMA are said to reflect the quest for more humane as well as more efficient ways of organizing destruction (Pinker, 2011; 2013; Singer, 2011). As NATO's chief spokesman Jamie Shea put it in response to Amnesty International's (2000) criticism of civilian deaths caused by the organization's 1999 Kosovo campaign, any civilian deaths caused by NATO members are the unfortunate results of technological malfunctions or "the accidents of conflict" (The Guardian, 2000). Such regrettable "accidents" and (correctable) malfunctions are thus construed as incitements to better manage, organize or equip the agencies of destruction. In terms of the concerns of this special issue, $21^{\text {st }}$ century virtual cum virtuous (Der Derian, 2009) warfare can be said to presuppose and require what Scarry (1985: 64) calls the "disowning of injuring": the derecognition of the essentially tragic nature of human conflict (Costea and Amiridis, 2013; Shah this issue).

In many ways, the Paris attacks appear paradigmatic of the hybrid, "asymmetrical" nature of much contemporary warfare (e.g. Kaldor, 1999; cf. Malešević, this volume). They represent the breakdown of the distinction between the orderly "everyday world" of offices, shopping malls and soccer games (Brooks, 2016) and the "ungoverned spaces" of the Other - a material-semiotic enactment of the "clash of civilizations" (Huntington, 1996). And yet, there seems to be an ironic symmetry between the strategies of destruction employed by both Western militaries as well as the Other side in the 'war on terror'. Whilst drones hide patiently in the skies dealing unseen death, terrorists also hide "in plain sight" among urban crowds and migrant flows as the UK's Chief of Defence Staff recently put it (quoted in Farmer, 2016: 2; see also CALL, 2011). To borrow from Bauman (2001: 15) the operations of both sides are strongly "reminiscent of the warfare strategy of nomadic tribes" who cultivate the "ability to descend from [seemingly] nowhere without notice and vanish again without warning”.

For many in the "ungoverned spaces" of Afghanistan, Iraq, Syria or Yemen, those whose lives have been ravaged by both sides in the "war on terror", there is little to choose between 
them: "Sometimes rockets are fired and sometimes it is suicide bombers and sometimes car bombs, and the victims are civilians" complains Niamatullah the schoolteacher, "[and] sometimes bombing by NATO coalition forces. It looks like Afghans are created by God to be killed by human machines" (quoted in the New York Times: Shah, 2009). Order and disorder do indeed appear to simultaneously threaten the world.

\section{Friday the 12th}

Another Friday, another place. On February $12^{\text {th }} 2010$ near the village of Khataba in Paktia province eastern Afghanistan, Mohammed Daoud Sharabuddin, a US trained police officer, newly promoted District Head of Intelligence, was hosting a party to celebrate the naming of his youngest son. At about 03:30 hrs. Daoud became aware of suspicious activity outside the compound. Suspecting an imminent Taliban or Haqqani (an affiliate of Al Queda) attack, Daoud and his fifteen year-old-son Sediqullah went out to investigate. They were hit by a hail of gunfire. Daoud's son was immediately killed and he himself mortally wounded. Five more members of the family, including three women - two of them pregnant - were killed or bled to death.

A few hours after the event, Brigadier General Eric Tremblay of the International Security Assistance Force (ISAF - the NATO-led Afghanistan expeditionary force) explained what took place. A Taliban attack had indeed occurred. A joint Afghan-ISAF patrol had happened upon it, killed a number of the attackers and called-in "expert medical support" for the injured. Eight men were detained for questioning. Tremblay took the opportunity to stress the contrast between ISAF and its Afghan partners (Order) and the Taliban insurgents (Disorder) "criminals and terrorists who do not care about the life of civilians" (Scahill, 2014: 338). A "senior US official" explained to CNN (2010) that the women were found bound and gagged and appeared to have been mutilated with knives. "It has the earmarks of a traditional honor killing," the official added, although it wasn't clear whether the "dishonor" for which the women were tortured and killed was "adultery or even cooperation with NATO forces" (ibid).

While the story was more or less faithfully reproduced by international news agencies, it soon started to unravel when local reporters started to interview witnesses: there was no Taliban attack. Instead it was an ISAF joint patrol that had opened fire on the compound. NATO now accepted that

"International forces were responsible for the deaths of three women who were in the same compound where two men were killed by the joint Afghan-international patrol 
searching for a Taliban insurgent...The force went to the compound based on reliable information in search of a Taliban insurgent and believed that the two men posed a threat to their personal safety...We now understand that the men killed were only trying to protect their families" (CNN, 2010).

According to local witnesses, the women's mutilations were the result of the American soldiers' attempt to dig out their bullets in order to prevent their weapons being identified. NATO investigators concluded that the women were killed accidentally when the patrol fired at the men. "The statement noted the women had been bound and gagged, but this information was taken from an initial report by the international members of the joint force who were not familiar with Islamic burial customs" the NATO statement concluded. It added that the organization would "apologize to the victims' family members and offer compensation in accordance with local customs" (CNN, op cit). It has been reported that Daoud's brother Mohammed Sabir (one of the eight men accidentally arrested) and whose wife was among those killed, was offered $\$ 2,000$ for each of his dead relatives. "He refused to take it" (CNN, op cit; cf. Butler, 2010). Sabir spoke of his grief: "I did not want to live anymore... I wanted to wear a suicide vest and blow myself [up] among the Americans. But my brother and father would not let me" (Scahill, 2014: 339).

We could read in the events of this day a similar narrative to that of the Paris attacks: peaceful Friday celebrations disrupted by violence and terror, which in turn adds momentum to the vicious cycle of injury and retribution. Through a managerialist lens, such events can be viewed as unfortunate accidents the future likelihood of which can (and ought to) be minimized through better organization, including more accurate information, more discipline, more training, more familiarization with local cultures and so on. Our own purpose in recounting the story is not to indulge in facile "anti-Westernism" (Buruma and Margalit, 2005). In terms of the concerns of the special issue, tragedies of this kind (of which there are far too many) underscore the referential instability of the key terms that in-form contemporary performances of 'organized' destruction. To reiterate, 'terror' and 'anti-terror', 'order' and 'disorder', the purveyors and the targets of violence appear to constantly swap masks.

\section{Concluding remarks: War and its inventions}

"War", argued Barack Obama in his 2009 Nobel Peace Prize acceptance speech, "appeared with the first man... it was simply a fact, like drought or disease - the manner in which tribes and then civilizations sought power and settled their differences". In a similar vein, historian 
Michael Howard (2000) writes of the "invention of peace". European societies, he notes, were for most of their history permanently organized for, or actively engaged in, warfare. Such societies were typically ruled by a warrior class and considered war as inevitable and peace as but an interval between wars. The idea that society could be permanently organized for peace rather than war was an Enlightenment innovation and it took a very long time before it became the official view in Western society. But although peace may be an invention, so arguably is war. Writing in 1940, while WWII was unfolding, anthropologist Margaret Mead (1990 [1940]) asked the question of whether war could be said to be

"a biological necessity, a sociological inevitability, or just a bad invention?...I wish to urge [the view] ... that warfare, by which I mean recognized conflict between two groups as groups, in which each group puts an army...into the field to fight and kill $\ldots$ is an invention like any other of the inventions in terms of which we order our lives, such as writing, marriage, cooking our food instead of eating it raw, trial by jury or [the] burial of the dead"

War (and peace), we might say, their agencies, spaces, technologies, and ethics, are subject to continual invention and re-invention. Indeed, the papers collected in this Special Issue, can be seen as focusing upon certain key moments and processes of (re)invention. Drawing on Weber, and broadly in line with Mead's argument, Siniša Malešević calls into question some of the dominant narratives that claim to explain the nature of organized violence in the $21 \mathrm{st}$ century - including Pinker's (2011) and Goldstein's (2011) “decline of armed conflict”, the Tofflers' (1990) “technological displacement” and Kaldor's (1999) “new wars” perspectives. In their place, he provides a detailed sociological analysis of organizational continuities and discontinuities that have characterised military and para-military violence up to the present. In 'Total Mobilisation, and the Work of War', Bogdan Costea and Kostas Amiridis draw on the writings of Ernst Jünger in order to make sense of one defining moment in the genealogy of contemporary modes of organized destruction. A controversial figure, Jünger (2016 [1924]) is best known in the Anglophone world for Storm of Steel his WWI memoir with its memorable descriptions of the savage exhilarations of war. Jünger's writing begins where Weber's ends and in spite of their obvious differences there are also important thematic continuities between the two writers. In Jünger's Der Arbeiter and Total Mobilisation, Weber's processes of rationalization, bureaucratization and the monopolization of violence are described at their apogee: when the figure of the soldier is demythologised and 
reconstituted as the "worker of destruction". The organization of production and the organization of destruction come to mirror each other more closely than ever.

In 'Killing Is Our Business', Leo McCann takes as his starting point another critical moment of war reinvention and techno-managerial experimentation: the time of Robert McNamara and the Vietnam War and its legacy for today's conflicts. Costea's and Amiridis's "Work of War" here acquires a new variant of "War Manager". "War managerialism" attempts to overcome the fog and friction of war by means of reliable metrics and business-like objectives. As is well known, the infamous 'body count' regime of what we might call (paraphrasing Mbembe, 2003) 'necromanagement', served to commit the US (even against McNamara's better judgement) to a disastrous war of attrition that it could not win. In 'How We Fight', Christopher Paparone addresses these same issues but from the perspective of a former professional member of the US military. Paparone's focus is on the development of US military doctrine and its continuing, if controversial, indebtedness to, often simplistic, managerialist metrics and idea(l)s. Both Paparone and McCann note how this persisting indebtedness is currently - linguistically and materially - expressed in the still on-going counterinsurgency operations (COIN in military acronymic speech) of the war(s) on terror.

The close 'family resemblances' between the practices of wealth making and war making - a point, as Costea and Amiridis remind us, originally made by Walther Rathenau - is a theme that cuts across a number of the papers in this special issue. In 'Organizing Destruction: a Derivative Logic', Simon Lilley and Geoff Lightfoot push this inquiry further, focusing on the spread of the financial derivative logic into national security and defense regimes. Against this backdrop, recent inventions such as the "Policy Analysis Market" (PAM) provide a fascinating clue as to how the sacrificial economy of war is being transformed in the neoliberal era. Finally, Nisha Shah, in 'Death in the Details', examines the institutionalisation of the memory of war and of its machineries of organized destruction. She takes Le Breton Gallery in the Canadian War Museum as a site for thinking about how the conventions of war become standardized in weapons technology. Whilst noting the apparent (and arguably deliberate) absence of killing or injury in the weapons' descriptions, she argues that weapons are not only the materiel, but also the materialization of discourses of, and claims for, war's legitimacy. 
Clearly, the articles in this special issue engage the (re)inventions of organized destruction from different angles and arrive at their conclusions via different analytical approaches. It is nevertheless apparent that the theoretical and policy questions upon which they touch should trouble prevailing conceptions of the scope and role of organizational studies. The main objective of the special issue then is to foster such emerging conversations across disciplines and perspectives and, hopefully, to facilitate the generation of new insights on the changing character of the agencies, forms and justifications of organized destruction in the contemporary world.

\section{Acknowledgements}

We would like to acknowledge the journal's financial support for the workshop on the theme of 'organized destruction' held at Lancaster University in 2014 as well as the editors' acceptance of our proposal for this Special Issue. Thanks also to the participants at that workshop for helping us clarify the themes explored here. In addition, we are indebted to the reviewers whose efforts facilitated the development of the articles included herein and Jill Meadows for her administrative assistance and patience throughout. Last but not least, we would like to thank our co-guest editor Lucy Suchman for her work on the special issue and comments on this introduction.

\section{References}

Abizaid, J.P. and Brooks, R. (2014) Recommendations and Report of The Task Force on US Drone Policy. Washington, DC: The Stimson Center.

Albrow M.(1970). Bureaucracy, London: Pall Mall.

Amnesty International Report (2000) 'Yugoslavia, Federal Republic of'. Online at: http://www.refworld.org/docid/3ae6aa1118.html.

Bauman, Z. (1989). Modernity and the Holocaust. Cambridge: Polity.

Bauman, Z. (2001). Wars of the Globalization Era. European Journal of Social Theory, $4(1): 11-28$.

BBC (2016a). 'Terrorism most immediate threat to UK, says MI6', December $8^{\text {th }}$. Online at http://www.bbc.co.uk/news/uk-38250432

BBC (2016b) 'Paris attacks planners 'killed in Syria', December $13^{\text {th }}$. Online at http://www.bbc.co.uk/news/world-us-canada-38306615

BBC (2017) 'Photos show 'weaponised commercial drones' in Iraq', January $18^{\text {th }}$. Online at http://www.bbc.co.uk/news/technology-38663394

Bentham, J. (2008 [orig.1791]) Panopticon; Or, the Inspection-House, London, Dodo Press.

Bergen, P. (2016) 'Trucks as killing machines: A frightening form of low-tech terror', CNN December $20^{\text {th }}$. Online at http://edition.cnn.com/2016/12/20/opinions/berlin-truckkilling-machines-bergen/index.html

Brook, R. (2016) How Everything Became War and the Military Became Everything: Tales from the Pentagon, Ney York: Simon \& Schuster. 
Burke, J. (1999). An Intimate History of Killing, London: Granta.

Buruma, I. and Margalit, A. (2005). Occidentalism: A Short History of Anti-Westernism, New York: Atlantic Books.

Butler, J. (2010). Frames of War. London: Verso.

CALL (Center for Army Lessons Learned) (2011) Commander's Guide to Biometrics in Afghanistan, Handbook No.11-25, Fort Leavenworth, KS.

Castells, M. (1996). The Information Age, Vol I. Oxford, Blackwell.

Cebrowski, A. and Garstka, J. (1998). Network-Centric Warfare: Its origins and future. Proceedings of the Naval Institute January,28-35. Retrieved from https://www.usni.org/magazines/proceedings/1998-01/network-centric-warfare-itsorigin-and-future

Chamayou, G. (2015). Drone Theory, London: Penguin.

Chwastiak, M. (2015). 'Torture as normal work', Organization, Vol.22(4):493-511.

Cimbala, S. (2012) Nuclear Weapons in the Information Age, Continuum.

CNN (2010). 'Man loses 5 family members in disputed NATO raid', Apri $6^{\text {th }}$. Online at: http://afghanistan.blogs.cnn.com/2010/04/06/man-loses-5-family-members-indisputed-nato-raid/

Coghlan, B., Brennan, R., Ngay, P., Dafara, D., Otto, B., Clements, M. and Stewart, T. (2006). 'Mortality in the Democratic Republic of Congo: A Nationwide Survey', The Lancet, Vol.367, January 7th.

Cooper, R (1986). Organization/Disorganization. Social Science Information, Vol.25(2):29935.

Corn, T. (2010) 'Peaceful Rise through Unrestricted Warfare', Small Wars Journal, June 5. Online at: http://smallwarsjournal.com/jrnl/art/grand-strategy-with-chinesecharacteristics

Costea, B. and Amiridis, K. (2013). Business Ethics and the Concept of the Tragic. Seminar presentation, University of Exeter, March $7^{\text {th }}$.

Costea, B. and Amiridis, K. (2017) 'Ernst Jünger, Total Mobilisation, and the Work of War', Organization 24(4): 475-490.

Deichmann, T. Reul, S. and Žižek, S. (2002). 'About War and the Missing Center in Politics', Eurozine: March $15^{\text {th }}$. Retreived from http://www.eurozine.com/pdf/2002-03-15zizek-en.pdf

Deleuze, G. (2007). Two Regimes of Madness: Texts and Interviews 1975-1995 Revised Edition. Semiotext(e).

Der Derian, J. (2009). Virtuous War: Mapping the Military-Industrial-Entertainment Network. London: Routledge.

Dillon, M. and Reid, J. (2009) The Liberal Way of War, London: Routledge.

Elias, N. (2000, [orig.1939]). The Civilizing Process. Oxford: Blackwell.

Elias, N. (1985). The Loneliness of the Dying, Oxford: Blackwell.

Farmer, B. (2016) 'Fleeing Jihadis 'hiding in plain sight with migrants', The Daily Telegraph, December $15^{\text {th }}: 2$. 
Freedman, L. (1998). 'The Revolution in Strategic Affairs', Adelphi Paper, London: IISS.

Foucault, M. (1979) Discipline and Punish, London: Allen Lane.

Garton Ash, T. (2000a). History of the Present, London: Penguin.

Garton Ash, T. (2000b). 'The war we almost lost', The Guardian, 4 September. Online at https://www.theguardian.com/world/2000/sep/04/balkans2

Gerth H.H. and Mills C.W. (eds) (1991 [orig.1948]) From Max Weber: Essays in Sociology, London: Routledge.

Godfrey, R., Lilley, S. and Brewis, J. (2012). Biceps, Bitches and Borgs: Reading Jarhead's Representation of the Construction of the (Masculine) Military Body. Organization Studies, 33(4),541-562.

Grayling, A.C. (2016). Among the Dead Cities: Was the Allied Bombing of Civilians in WWII a Necessity or a Crime? London: Bloomsbury.

Gregory, D. (2011). 'The everywhere war', The Geographical Journal, Vol.177(3):238-250.

Grey, C. (2009). Security Studies and Organization Studies: Parallels and Possibilities. Organization, 16(2):303-316.

Grint, K. (2008). Leadership, Management and Command, London: Palgrave.

Goldstein, J.L.(2011) Winning the War on War: the Decline of Armed Conflict Worldwide, New York: Plume.

Grossman, D. (2009). On Killing, New York: Back Bay Books.

Hallin, D. (1986). The Uncensored War: The Media and Vietnam, Los Angeles: University of California Press.

Hastings, M. (2010). Bomber Command, London: Pan.

Hobbes, T. (1968 [orig.1651]). Leviathan, Harmondsworth: Penguin.

Howard, M. (2000). The Invention of Peace, London: Profile Books.

Huntington, S. (1996). The Clash of Civilizations and the Remaking of World Order, New York: Simon \& Shuster.

Jünger, E. (2016 [orig.1924]). Storm of Steel, London: Penguin.

Ignatieff, M. (2000a). Virtual War: Kosovo and Beyond. London: Chatto \& Windus.

Ignatieff M. (2000b). 'The New American Way of War', The New York Review of Books, 47/12:July 20. Online at: http://www.nybooks.com/articles/2000/07/20/the-newamerican-way-of-war/

Kaldor M. (1999). New \& Old Wars: Organized Violence in a Global Era, Palo Alto: Stanford University Press.

Lefebvre, S., Fortmann M., and Congora T. (1996). The Revolution in Military Affairs, Its Implications for Doctrine and Force Development Within the US Army. In B.J.C. McKercher and M.A. Henessy (eds.), The Operational Art, Development on the Theories of War, London: Praeger:173-192

Lilley, S. and Lightfoot, G. (2017) ' Organizing Destruction: A Derivative Logic?', Organization 24(4): 534-548. 
Luttwak E.N. (1995). 'Towards Post-Heroic Warfare', Foreign Affairs, May/June. Online at: https:/www.foreignaffairs.com/articles/chechnya/1995-05-01/toward-post-heroicwarfare

Luttwak E.N. (1999). 'Give War a Chance', Foreign Affairs, July/August. Online at: https:/www.foreignaffairs.com/articles/1999-07-01/give-war-chance

MacDiarmid, C. (2017). 'ISIL adapts drones to drop bombs on markets in liberated areas', The Sunday Telegraph, January $15^{\text {th }}: 13$.

MacRae D.G. (1974) Weber, London: Harper Collins.

Malešević, S. (2017) 'The Organisation of Military Violence in the 21st Century', Organization 24(4): 456-474.

Marlantes, K. (2012) What It Is Like To Go To War, London: Corvus.

Marvin, C. and Ingle, D. (1999). Blood sacrifice and the nation, Cambridge, Cambridge University Press.

Mbembe, A. (2003). 'Necropolitics’ Public Culture, Vol.15(1): 11-40.

McCann, L. (2017) “"Killing Is Our Business and Business Is Good”: The Evolution of "War Managerialism" From Body Counts to Counterinsurgency', Organization 24(4): 491515.

Mead, M. (1990 [orig. 1940]). 'Warfare is Only an Invention - Not a Biological Necessity' in D.Hunt (ed). The Dolphin Reader, Boston: Houghton Mifflin: 415-21.

Menon, R. (2016) The Conceit of Humanitarian Intervention, Oxford: Oxford University Press.

Moore, J. (2016).'Two members of Jihadi John's 'Beatles' execution cell named as Alexe Kotey and Aine Davis', Newsweek, Febuary 8. Online at: http://europe.newsweek.com/members-jihadi-john-beatles-execution-cell-namedalexe-kotey-aine-davis-423907? $\mathrm{rm}=\mathrm{eu}$

Nearing, S. (1931) War: organized destruction and mass murder by civilized nations, New York: Vanguard Press.

Obama, B. (2009). 'Remarks by the President at the Acceptance of the Nobel Peace Prize'. Online at: https://www.whitehouse.gov/the-press-office/remarks-presidentacceptance-nobel-peace-prize

Paparone, C. (2017) 'How We Fight: A Critical Exploration of US Military Doctrine', Organization 24(4): 516-533.

Parsons, T. (1937) The Structure of Social Action. New York: Free Press.

Parsons, T. and Henderson, A.H. (1947) The Theory of Social and Economic Organization, Glencoe IL: Free Press.

Pickering, A. (2001). Practice and posthumanism; Social theory and a history of agency. In T. Schatzki, K. Knorr-Cetina and E. Von Savigny (Eds.) The Practice Turn in Contemporary Theory (pp.163-173). London: Routledge.

Pinker, S. (2011). The Better Angels of our Nature. London: Allen Lane.

(2013). 'The Real Risk Factors for War'. Retrieved from https:// www.edge.org/response-detail/23665 
Qiao, L. and Wang, X. (1999) Unrestricted Warfare. Beijing: PLA Publishing House.

Ramo S. (2011). Let Robots do the Dying, The Coming Partnership of Man and Robots in the US Military, Los Angeles CA: Figueroa Press.

Reyntjens, F. (2011). The Great African War: Congo and Regional Geopolitics: 1996-2006, Cambridge: Cambridge University Press.

Scahill, J. (2014) Dirty Wars: The World is a Battlefield, London: Serprent's Tail.

Sebald, W. G. (2003) On the Natural History of Destruction. London, Penguin.

Shah, N. (2017) 'Death in the Details', Organization 24(4): 549-569.

Shah, T. (2009) 'Bombing Deepens Despair in a Stricken Afghan City', The New York Times, August 26. Online at http://www.nytimes.com/2009/08/27/world/asia/27kandahar.html

Singer, P. (2011). Is Violence History? The New York Times, 6 October. Retrieved from http://www.nytimes.com/2011/10/09/books/review/the-better-angels-of-our-natureby-steven-pinker-book-review.html

Scarry, E. (1985) The Body in Pain: The Making and Unmaking of the World, Oxford: Oxford University Press.

Snow C.P. (1960) Science and Government: The Godkin Lectures at Harvard University, Oxford, Oxford University Press.

Taylor, A.J.P. (1961) The Origins of the Second World War, Athenaeum.

Taylor, A.J.P. (1969) War by Timetable, New York, Heritage.

Taylor, A.J.P. (1970) English History 1914-1945. Harmondsworth: Penguin.

The Guardian (2000) 'Amnesty accuses Nato of war crimes', June $7^{\text {th }}$. Online at https://www.theguardian.com/world/2000/jun/07/balkans1

Toffler, A. (1991) 'A New Theory of Warfare: The Third Wave Arrives', Los Angeles Times, March $5^{\text {th }}$. Online at; http://articles.latimes.com/1991-03-05/local/me-22 1 worldwar

Toffler, A. and Toffler, H. (1992) Powershift: On Knowledge, Wealth and Violence at the Edge of the 21st Century, Bantam Books.

Tsoukas, H. (1998). 'Introduction: Chaos, Complexity and Organizational Theory', Organization, Vol.5(3):191-313.

Tuchman, B. (1990) The March Of Folly: From Troy to Vietnam, Abacus.

Weber, M. (2004 [orig.1919]) The Vocation Lectures, Indianapolis: Hackett.

Whitehead, N. and Finnström, S. (2013). Virtual War and Magical Death, Duke University Press.

\section{Notes}

\footnotetext{
${ }^{1}$ For instance, explorations of the "dark side of organization" seldom touch upon what is surely the 'dark side's' most evident manifestation.
} 
${ }^{2}$ For example, in World War II, the Ministry of Supply was Britain's largest employer and was responsible for 42 Royal Ordnance factories and 300,000 workers. To ensure their satisfaction with their work, 600 labour officers and 5500 welfare officers were employed in arsenals, there were 46 new Whitley councils established and there were 2000 joint production committees taking their lead from the ordinance factories. Historically, legislation and policies on industrial relations have often been led by concerns for the performance and welfare of workers within the arsenal (see for example the House Hearings in the USA concerning the Watertown Arsenal in 1911).

${ }^{3}$ In March 1942 the British War Cabinet had agreed the so-called Lindemann plan, which urged that Allied bombing should "be directed essentially against German working-class houses. Middleclass houses have too much space round them and so are bound to waste bombs; factories and "military objectives" had long since been forgotten, except in official bulletins, since they were much too difficult to find and hit. The [Lindemann] paper claimed that - given a total concentration of effort on the production and use of aircraft- it would be possible, in all the larger towns of Germany (that is, those with more than 50,000 inhabitants), to destroy 50 per cent of all houses." (Snow, 1960: 47-48)

${ }^{4}$ NATO claimed to have destroyed some 120 Serbian tanks, 220 armored personnel carriers, and 450 artillery and mortar pieces. But the Serbian armoured columns that withdrew from Kosovo looked in remarkably good shape. According to a suppressed US Air Force report obtained by Newsweek, Nato verifiably destroyed just 14 tanks, 18 armored personnel carriers, and 20 artillery pieces.

${ }^{5}$ Possibly another member of the 'Beatles' cell. Emwazi (born Muhammad Jassim Abdulkarim Olayan al-Dhafiri) gained his 'Jihadi John' nickname as part of a four member ISIL cell known as 'the Beatles' because of their British accents. There were reports that 'the Beatles' struggled with Arabic and spoke among themselves in English (Moore, 2016).

${ }^{6}$ It is worth noting however that terrorist organizations are themselves, increasingly, users of drones (e.g. BBC, 2017; MacDiarmid, 2017).

\section{Author Biographies}

Brian P. Bloomfield is a Professor of Technology and Organization in the Department of Organisation, Work \& Technology at Lancaster University, UK. His research interests include social imaginaries and the promotion of, and resistance to, technoscientific innovations; debates about human enhancement technologies and post-humanism and theorizations of sociomateriality. He has published in the fields of organization studies, sociology and science and technology studies.

Gibson Burrell is too young to have faced conscription, has never served in the armed forces, has never been to war, has never visited an active war zone and has not really seen street violence of any note. Many would be thankful for this and so is he. Nor has he demonstrated against the state anywhere near enough in his lifetime. This, however, is a huge regret.

Theo Vurdubakis is a Professor of Organization and Technology in the Department of Organisation, Work \& Technology, at Lancaster University, UK. His research interests include the handling of complexity and the role of technological practices and artefacts in performances of social organization. In his younger days he did a short(ish) spell in the military which however felt much longer at the time. 